\title{
Memórias sobre o colonialismo europeu na África
}

\author{
Sebastião André Alves de Lima Filho
}

Preciso manter a promessa de não fazer um discurso sobre o colonialismo. Mas vou expressar, com palavras simples, qual é a minha objeção fundamental ao domínio colonial. A meu ver, é um grave crime qualquer pessoa se impor a outra, apropriar-se de sua terra e de sua história, e ainda agravar esse crime com a alegação de que a vítima é uma espécie de tutelado ou menor de idade que necessita de proteção. É uma mentira total e deliberada. Parece que até o agressor sabe disso, e é por essa razão que ele às vezes procura camuflar seu banditismo com essa hipocrisia tão descarada." (Chinua Achebe).

\section{$\overline{\text { Sebastião André Alves de }}$ Lima Filho}

Professor Adjunto da UNILAB e pesquisador do Observatório das Nacionalidades. $\overline{\text { ACHEBE, Chinua. A educação de uma }}$ criança sob o protetorado britânico. São Paulo: Companhia das Letras, 2012.

A promessa não cumprida contida neste excerto, escrita pelo nigeriano Chinua Achebe sobre as consequências do colonialismo europeu na África, ecoa nos dezesseis ensaios que compõem a obra de sua autoria, intitulada A educação de uma criança sob o protetorado britânico. A partir da descrição de eventos que experimentou, ou presenciou na Nigéria dominada pelos britânicos, os escritos ensaísticos de Achebe narram, principalmente, as consequências da interferência estrangeira no ritmo de vida social das populações africanas.

Chinua

Achebe

é considerado um dos mais importantes escritores de literatura africana do século XX. Nascido na Nigéria em novembro de 1930, cresceu testemunhando os efeitos trágicos da Partilha da África pelas potências europeias. Espectador 
atento dos dilemas da vida social em ebulição por conta da presença "dos brancos", Achebe vivenciou as profundas mudanças verificadas na estrutura social na aldeia de Ogidi, na qual nascera, bem como assistiu, do lugar privilegiado, a luta de independência da Nigéria encenada no palco da história montado pelos imperialistas britânicos.

De fato, a história de vida de Chinua Achebe desloca-se próximo das transformações políticas, sociais, econômicas e culturais que sacudiram a Nigéria e a África a partir da segunda metade do século XX, favorecendo o acúmulo de conhecimentos e experiências acerca da introdução de novas instituições e percepções nas sociedades africanas oriundas de sistemas sociais exógenos. É com base nesse cabedal de informação acumulado ao longo da sua existência que Achebe preenche os ensaios integrantes do livro A educação de uma criança sob o protetorado britânico.

O primeiro ensaio, que é batizado com o título do livro, resgata cenas, lembranças e dilemas de vida do autor através da sua jornada juvenil de descobrimento do mundo e de socialização. Como já indicado, o cenário que define as fronteiras das suas recordações é o sistema colonial britânico, que avança lentamente, como o Rio Níger, no território africano nomeado de Nigéria.

Assim, quando começa a descrever a cultura e os traços de identidade da etnia à qual pertence - os igbo -, não deixa de lembrar o impacto do colonialismo na vida da comunidade. Achebe (2012) compara de lampejo o casamento igbo com o colonialismo.

Os igbo não têm fantasias otimistas sobre $\mathrm{o}$ mundo. Sua poesia não celebra o amor romântico. Eles têm um provérbio, que minha mulher detesta, no qual a mulher diz que não faz questão de ser amada pelo marido, contanto que ele ponha inhame na mesa do almoço todos os dias. [...] O domínio colonial foi mais forte do que qualquer casamento. Os igbo lutaram contra ele no campo de batalha e perderam. Ergueram todas as barricadas possíveis para detê-los, e perderam novamente (p. 16). 
O impacto do colonialismo na vida dos africanos parece que atormentou a pena de Chinua Achebe quando escreveu os ensaios componetes da obra. O tema da disputa de orientações de mundo entre o colonizador e o colonizado baliza o conjunto dos escritos. No ensaio primeiro e no sétimo, intitulado "Dizendo nosso verdadeiro nome", o papel que a religião cristã desempenhou na sedução dos espíritos dos povos autóctones da África, conduzidos no labirinto da vida social por outros elementos de representação simbólica e ritual que animavam a religiosidade africana, é mencionado.

É bem conhecida a discussão sobre a função da cruz e dos evangelhos na estratégia de dominação dos europeus na África. Embora Chinua Achebe não descreva as características da "personalidade cristã" nas suas digressões sobre a influência do cristianismo na África, de maneira geral, e na Nigéria, em particular, um traço não escapa das suas memórias: a persistência incansável em converter almas em nome de Roma.

Com efeito, em muitas passagens de memórias, a descrição da presença e influência da Igreja romana na Nigéria é apontada.

Foi pura desfaçatez minha sugerir, no início deste relato, uma comparação entre minha insignificante história e a história de Moisés. Seria como um pirilampo se comparar à luta cheia. Peço desculpas. Eu me deixei levar pelo entusiasmo. Mas é verdade que a aldeia de Ogidi me vigiava, de maneira sub-reptícia, através do exílio do cristianismo. Meu rio, porém, não era o Nilo, e sim o Níger. De fato, nosso título oficial era "diocese no Níger". Não "do Níger", mas "no". Nosso bispo era bispo no Níger ( p. 21).

Em outras narrativas, o papel social da cristianização dos africanos da aldeia de Ogidi é detalhado a partir das sinuosas vias entre o que é considerado sagrado e profano e a assimilação do ethos cristão.

Entre a igreja e a aldeia, havia por vezes uma diferença de assunto na linguagem falada, mas não na maneira de se expressar. Em ambas havia grandes oradores. Os cristãos da geração do meu pai, que pregavam aos domingos na igreja de Saint Philip, não eram oradores, mas 
um bom número deles era. Embora a Igreja Anglicana, numa tentativa equivocada de unificação, tivesse desferido um duro golpe contra a língua igbo, impondo a ela um mecânico dialeto de união, essa linguagem híbrida assim criada ficava confinada entre as duas capas da Bíblia, e não vinha colocar peias no estilo dos pregadores mais sensatos, depois que liam seu texto obrigatório e fechavam a Bíblia. Um desses pregadores era conhecido por subir ao púlpito na época das festividades da aldeia e alertar os verdadeiros crentes contra o mal de aceitar doações de alimentos passados sub-repticiamente por cima do muro por vizinhos pagãos. Obviamente, havia um trânsito intenso nessas passagens. Os cristãos tinham suas próprias festas, é claro: a grande, o Natal, e a pequena, a Páscoa, embora os ministros sempre nos dissessem que era o contrário ( p. 23).

Achebe nos faz lembrar que o colonialismo impusera, por conta da evangelização, uma variedade de ritos sagrados. No entanto, o escritor nigeriano anota que o colonizador britânico não importou apenas os rituais sagrados praticados na metrópole. Introduziu, também, os "rituais profanos", como o Dia do Império.

Chinua Achebe narra, em detalhes, quais foram suas impressões no "seu primeiro Dia do Império". Lembra que o evento mobilizava todo o distrito. As escolas preparavam desfiles, competições esportivas eram travadas, danças e músicas animavam as celebrações dos conquistadores diante do governador britânico da colônia, postado em um estrado elevado, vestido com "seu uniforme cerimonial todo branco, luvas brancas, capacete emplumado e espada na cintura".

O Dia do Império era comemorado em 24 de maio. Nessa mesma data, celebrava-se o aniversário da rainha Vitória. A unificação dos dois eventos em uma só data expressava profundo simbolismo na dinâmica de poder do Estado britânico que acompanhou o imaginário político daqueles que desenharam os quadrantes da administração colonial do Império Britânico.

Ao que tudo indica, a construção da ideia de "império britânico" aglutinou-se ao conceito de "Os dois corpos do 
rei", herança dos fundamentos da monarquia inglesa que remonta aos tratados de teologia política medieval. Como bem lembrou Kantorowicz (1998, p. 23),

$\mathrm{Na}$ Inglaterra do século XVI, uma questão legal relativamente simples podia, muitas vezes, levar os juristas a discussões que pareciam mais apropriadas a um teólogo se não dissessem respeito à pessoa do rei, ou, mais exatamente, aos dois corpos do rei. Segundo uma doutrina aceita por todos, o rei possuía um corpo natural, como qualquer outro homem, e, além disso, um "corpo místico", invisível e imortal, incapaz de qualquer imperfeição. Os Dois Corpos do Rei, dessa forma, constituem uma unidade indivisível, sendo cada um inteiramente contido no outro. Entretanto, não pode haver dúvida em relação à superioridade do corpo político sobre o corpo natural.

Nas impressões descritas por Chinua Achebe acerca das peculiaridades da organização social e política do Protetorado Britânico na Nigéria a busca de legitimidade dos colonizadores britânicos na África não se baseava apenas nos discursos que enfatizavam a superioridade racial e civilizacional dos brancos. Orientava-se, também, pela difusão de tradições que sustentavam a realeza britânica.

O olhar de Chinua Achebe recai sobre as práticas e as estratégias de poder usadas pelo colonialismo no intuito de garantir a dominação de grandes regiões do continente africano. O manejo de rituais, cerimônias, comemorações de eventos cívicos que reforçavam a identidade nacional britânica nas colônias, descritos por Achebe, favorecia a assimilação dos autóctones ao campo de influência dos britânicos.

As memórias que Chinua Achebe narra em seu livro são eventos que resultaram de um prolongado processo de colonização e expropriação de grandes contingentes populacionais. As lembranças narradas são fragmentos de contextos sociais profundamente alterados em virtude da chegada de colonizadores europeus na África. Suas narrativas fornecem elementos de compreensão das engrenagens postas em movimento pelo colonialismo no intento de romper com 
as configurações sociais das sociedades africanas.

O conceito de "desencaixe", de Anthony Giddens (1991), poderia ser utilizado para guiar o entendimento de como o "choque de civilizações" provocou profundas rupturas nas orientações de mundo dos povos nigerianos descritas por Chinua Achebe. Do mesmo modo, a noção de "desencra$v^{\prime \prime}$, de Pierre Chaunu (1984), serve de amparo teórico no sentido de compreender a dinâmica social a partir do contato entre europeus e africanos. Ambos os conceitos indicam a desarticulação de crenças, valores e visões de mundo que sustentavam as estruturas das organizações sociais dos africanos da Nigéria.

Todo processo de "desencaixe" das relações sociais fomenta a construção de novos elementos de orientação no mundo social, provocando "reencaixes" de crenças, valores e percepções de mundo no tecido social em redefinição. Em uma passagem do ensaio intitulado $O$ que é a Nigéria para mim?, Achebe (2012, p.48) descreve o traumático processo de "reencaixe" no sistema político nigeriano com a introdução da ideia de identidade nacional, assimilado a partir das práticas políticas dos colonizadores.

O paradoxo de Biafra era que os próprios igbo tinham, de início, defendido a ideia de uma nação nigeriana com mais entusiasmo que outros nigerianos. Prova disso é que os britânicos jogaram mais igbo na prisão por sublevação do que qualquer outra etnia durante as duas décadas de agitações e revoltas pré-independência. Assim, os igbo estavam em primeiro lugar na frente nacionalista quando a Grã-Bretanha finalmente concedeu a independência à Nigéria em 1960 - um gesto que, quando se olha para trás, parece um golpe de mestre: fazer uma retirada tática para conseguir uma suprema vantagem estratégica.

E continua a descrever, com fortes tonalidades de decepção, as consequências de construir, na Nigéria, um Estado-nação de acordo com a arquitetura política ocidental.

Meu sentimento em relação à Nigéria foi de profunda decepção. Não porque havia gangues caçando e matando civis inocentes com a mais brutal selvageria em muitas partes do norte 
da Nigéria, mas porque o governo federal nada fez, deixando isso acontecer. Como o Estado não cumpriu sua obrigação básica para com seus cidadãos, a consequência foi a secessão do leste da Nigéria, originando a República de Biafra. Naquele momento, o colapso da Nigéria só foi evitado pelo apoio ativo da Grã-Bretanha, diplomático e militar, à sua colônia-modelo. Foi a Grã-Bretanha e a União Soviética que, juntas, esmagaram o nascente Estado de Biafra. No fim dessa guerra de trinta meses, Biafra era um imenso monte de entulho fumegante. O custo em vidas humanas foi escandaloso: 2 milhões de almas, em uma das mais sangrentas guerras civis da história humana (p. 51).

Apesar do título, o livro de Chinua Achebe pouco descreve o papel da educação de uma criança sob o protetorado britânico. O principal tema a perpassar todos os ensaios é o da dinâmica da violência, física e simbólica, do colonialismo europeu na África.

De fato, a reflexão de Chinua recai, várias vezes, sobre as estratégias de desumanização dos africanos usadas pelo colonialismo no intuito de legitimar a ocupação da África, com a finalidade de extorquir os recursos naturais do continente. Uma dessas estratégias, já teorizada por Edward Said (2011), era o uso da literatura como meio de hierarquizar, inferiormente, as práticas sociais dos povos africanos.

Há várias alusões, por exemplo, ao livro de Joseph Conrad, Coração das trevas. O que objetiva Chinua Achebe ao citar o livro do escritor inglês? Desconstruir a visão bárbara e selvagem que as palavras de Conrad lançaram sobre as sociedades africanas. Porém, Achebe não apaga o fundo de verdade desenhado por Conrad com base nas suas experiências, como marinheiro, no Congo do rei Leopoldo.

A descrição da violência semeada na África pelo colonialismo, detalhada por Joseph Conrad em um estilo literário totalmente oposto ao comportamento humano que presenciou nas margens do Rio Congo, se tornou um dos mais conhecidos testemunhos da maldade humana no cobiçado continente africano. Como anotou Hochschild (1999, p. 153), 
O coração das trevas é a experiência [...] levada um pouco (e muito pouco) para além dos fatos reais referentes ao caso. Quaisquer que sejam os níveis de significado que tenha o livro, como literatura, para nossos propósitos o notável é a precisão e a descrição detalhada dos fatos reais referentes ao caso: o Congo do rei Leopoldo, em 1890, assim como a exploração do território, tinha começado para valer.

Implicitamente, Chinua Achebe toma como ponto de partida das suas reflexões, em quase todos os ensaios, as consequências do momento em que o colonialismo britânico tinha começado na Nigéria. É como se em cada ensaio encontrássemos as digitais do livro de Achebe $O$ mundo se despedaça, no qual sintetiza os efeitos da conquista britânica da sua região.

Por isso nos ensaios, apesar de abordar um leque díspare de temas, como as peculiaridades da cultura igbo, a importância ou não da língua inglesa para o reconhecimento da literatura africana, até a imagem deturpada da África em livros infantis, o denominador comum, que perpassar todos os escritos, é a questão de encontrar as respostas para os dilemas do "viver africano", em um mundo cada vez mais sitiado pelo modo de vida do mundo ocidental.

É esta a nossa conclusão ao ler o ensaio intitulado A África é gente de verdade. Talvez este ensaio seja a síntese de todos os outros. Nele, Chinua Achebe ecoa "aos donos do mundo" que o problema que mais asfixia os africanos não é de matiz econômica, política ou cultural. Pelos menos não compreendido separadamente. A África não deve ser vista como um continente homogêneo de países, insensivelmente congelado no tempo em mapas traçados arbitrariamente pelos colonialistas do século XIX. Pelo contrário, é um lugar de indivíduos reais, modos de vida cujos significados sociais que atribuem às suas ações jamais entenderemos em sua totalidade, cujas vidas são desperdiçadas pelos problemas ora descritos, mas que não se resume a eles.

Outro ensaio a chamar a atenção, e que complementa os demais, é O nome difamado da África, onde Chinua Achebe examina o legado histórico de séculos de espoliação colonialista, além de discorrer sobre 
a construção da imagem que realça o continente africano como um todo compacto, reconhecido apenas pelo primitivismo, guerras genocidas e miséria que assola as sociedades que habitam o continente.

O referido ensaio pode ser compreendido como uma síntese dos eventos desencadeados pelo processo histórico de longa duração, que fizeram da África um continente condenado a representar, no palco da história, apenas o lado mais tenebroso das atitudes humanas. Achebe resume (2012, p. 84) com as seguintes palavras:

O vasto arsenal de imagens depreciativas da África que foram coletadas para defender $\mathrm{O}$ tráfico de escravos e, mais tarde, deu ao mundo uma tradição literária que agora, felizmente, está extinta, mas deu também uma maneira particular de olhar [ou melhor, de não olhar] a África e os africanos que, infelizmente, perdura até hoje. Assim, apesar de os impressionantes romances "africanos", tão populares no século XIX e início do século $\mathrm{XX}$, terem rareado até praticamente acabar, a obsessão secular que revelam pelos estereótipos escabrosos e degradantes da África passou para o cinema, o jornalismo, certos ramos da antropologia e até mesmo para o humanismo e o trabalho missionário.

A importância do livro de Chinua Achebe reside na capacidade de desconstruir a imagem da África como um espaço de vida social alheio à dignidade humana. Os ensaios são, também, fragmentos resumidos de um quebra-cabeça que mostra o retrato fiel da cobiça do civilizado no percurso de espoliação de milhões de africanos.

\section{Referências}

ACHEBE, C. . $\mathbf{0}$ mundo se despedaça. São Paulo: Companhia das Letras, 2012.

CHAUNU, P. Conquista e exploração de novos mundos. São Paulo: Editora da USP, 1984.

GIDDENS, A.Asconseqüências da modernidade. São Paulo: Editora da UNESP, 1991.

HOCHSCHILD, A. O fantasma do rei Leopoldo. São Paulo: Companhia das Letras, 1999.

KANTOROWICZ, E. H. Os 
dois corpos do rei. Um estudo sobre teologia política medieval. São Paulo: Companhia das Letras, 1998.

SAID, E. Cultura e imperialismo. São Paulo: Companhia das Letras, 1995. 